\title{
Pseudomonas putida Strain PCL1444, Selected for Efficient Root Colonization and Naphthalene Degradation, Effectively Utilizes Root Exudate Components
}

\author{
Irene Kuiper, ${ }^{1}$ Lev V. Kravchenko, ${ }^{2}$ Guido V. Bloemberg, ${ }^{1}$ and Ben J. J. Lugtenberg ${ }^{1}$ \\ ${ }^{1}$ Leiden University, Institute of Molecular Plant Sciences, Clusius Laboratory, Wassenaarseweg 64, 2333 AL Leiden, The \\ Netherlands; ${ }^{2}$ All-Russia Research Institute for Agricultural Microbiology, Podbelsky Shossee 3, Puskin 8, St Petersburg, \\ 189620, Russian Federation.
}

Submitted 10 September 2001. Accepted 23 March 2002.

Previously, we have described the selection of a plant-bacterium pair that is efficient in rhizoremediating naphthalene pollution in microcosm studies. After repeated selection for efficient root tip colonization upon inoculation of seeds of grass cv. Barmultra and for stable and efficient growth on naphthalene, Pseudomonas putida PCL1444 was selected as the most efficient colonizer of Barmultra roots. Here, we report the analysis of Barmultra root exudate composition and our subsequent tests of the growth rate of the bacterium and of the expression of the naphthalene degradation genes on individual exudate components. High performance liquid chromatography analysis of the organic acid and sugar root-exudate components revealed that glucose and fructose are the most abundant sugars, whereas succinic acid and citric acid are the most abundant organic acids. Tn5luxAB mutants of PCL1444 impaired in naphthalene degradation appeared to be impaired in genes homologous to genes of the upper naphthalene degradation pathway present in various Pseudomonas strains and to genes of the lower pathway genes for naphthalene degradation in $\boldsymbol{P}$. stutzeri. Highest expression for both pathways involved in naphthalene degradation during growth in minimal medium with the carbon source to be tested was observed at the start of the logarithmic phase. Naphthalene did not induce the upper pathway, but a different pattern of expression was observed in the lower pathway reporter, probably due to the conversion of naphthalene to salicylic acid. Salicylic acid, which is described as an intermediate of the naphthalene degradation pathway in many Pseudomonas strains, did induce both pathways, resulting in an up to sixfold higher expression level at the start of the logarithmic phase. When expression levels during growth on the different carbon sources present in root exudate were compared, highest expression was observed on the two major root exudate components, glucose and succinic acid. These results show an excellent correlation between successful naphthalene rhizoremediation by the Barmultra- $P$. putida PCL1444 pair and both efficient utilization of the major exudate components for growth and high transcription of the naphthalene catabolic genes on the major exudate components. Therefore, we hypothesize that efficient root colonizing and naphthalene degradation is the result of the applied colonization enrichment procedure.

Corresponding author: Irene Kuiper; Telephone: (+31)-71-5275076; Fax: (+31)-71-5275088; E-mail: kuiper@ rulbim.leidenuniv.nl
The large number and size of areas contaminated with polycyclic aromatic hydrocarbons requires new innovative methods to restore polluted sites in an inexpensive, environmentally friendly way. For this purpose, phytoremediation is a technique with great potential (Bizily et al. 2000; Gleba et al. 1999; Meagher 2000). It can function as a "green" pump and treatment system by attracting water with dissolved xenobiotics toward the root system (Erickson 1997). The rhizosphere can be very relevant in phytoremediation because, due to the exudation of nutrients, microbial populations in the rhizosphere are much larger compared with those in rootless bulk soil. Microbes can degrade a diverse range of pollutants (Anderson et al. 1993; Aprill and Sims 1990; Kingsley et al. 1994; Schwab et al. 1995; Walton and Anderson 1990; Yee et al. 1998); therefore, phytoremediation can be enhanced by introduction of these microbes into the rhizosphere.

Previously, we have described the isolation of Pseudomonas putida strain PCL1444 from the rhizosphere of grasslike vegetation from a polycyclic aromatic hydrocarbons (PAH)-polluted site. This strain is able to degrade naphthalene very efficiently in the rhizosphere and uses the root system as a vehicle to penetrate barriers which normally are impermeable for bacteria. In addition, this strain is able to protect grass seeds and seedlings against high naphthalene concentrations (Kuiper et al. 2001). In this study, we try to elucidate the molecular basis behind the selection of this plant-bacterium pair and its ability to protect grass against high naphthalene concentration and efficient degradation of naphthalene in the rhizosphere. The nutrient conditions in the rhizosphere depend largely on the root exudate and different plant species can have different effects on the rhizosphere population by means of their exudate composition (Lynch and Whipps 1990; Rovira 1956). For that reason, the composition of the carbon sources in the root exudate of grass cv. Barmultra was analyzed with regard to organic acids and sugars. Subsequently, the influence of these root exudate components on the growth of PCL1444 was tested. During growth on the individual exudate components, the transcription of the naphthalene degradation genes of PCL1444 in the rhizosphere was determined using Tn 5 lux $A B$ reporter strains.

\section{RESULTS}

Composition of sugar and organic acid content in grass seed, seedling, and root exudate of grass cv. Barmultra.

Analysis of the exudates of Barmultra grass showed that succinic acid was by far the most dominant organic acid, 
followed by citric acid and malic acid (Table 1). The total amount of organic acids found in 4-day-old seedling exudate was 1.5 times that found in 2-day-old seed exudate, whereas the total amount in root exudate was twice that found in seedling exudate.

Seed exudate was very rich in arabinose, but this gradually disappeared after germination and was not detected anymore in root exudate (Table 1). In the other exudates, glucose was the primary compound, followed by fructose.

Comparison of the total amount of organic acids and sugars showed that the ratio of organic acids and sugars (wt/wt) in the seed exudate was 0.6 , whereas this ratio changed to 1.1 in seedling exudate and 1.3 in plant root exudates, respectively.

\section{Identification of genes of $P$. putida PCL1444 involved in naphthalene degradation.}

In order to obtain PCL1444 mutants impaired in their ability to degrade naphthalene, a library of PCL1444 consisting of $6000 \operatorname{Tn} 5$ lux $A B$ insertion mutants was established. Mutants were screened for their inability to grow on basic medium (BM) medium (Lugtenberg et al. 1999) in which standard carbon source succinic acid was replaced by naphthalene, resulting in the selection of 33 putative mutants. After 3 days of incubation on BM-naphthalene, 5 of the 33 selected mutants showed delayed growth. All mutants appeared to be able to grow on standard BM medium (Lugtenberg et al. 1999), indicating that they had no auxotrophies. Based on no growth or delayed growth on BM-naphthalene, on differences in colony pigmentation in the presence of naphthalene indicative for accumulation of degradation intermediates, and on $\operatorname{lu} x A B$ gene expression indicative for transposon insertion in the same direction of transcription as the naphthalene catabolic genes, mutants PCL1455, PCL1456, PCL1470, PCL1471, PCL1472, and PCL1475 were chosen for further characterization (Table 2). In addition, PCL1454, in which the $\operatorname{Tn} 5 \operatorname{lux} A B$ is inserted in a DNA region between the $\operatorname{dox} G$ homologue and the $\operatorname{doxH}$ homologue of Pseudomonas spp. strain C18 (Denome et al. 1993) as described previously by Kuiper and associates (2001) (Fig. 1), was used for further studies.
Results of the comparison of the sequenced chromosomal regions flanking the Tn5 insertion with the database are shown in Table 2. A schematic overview of the location of the Tn5luxAB insertion in the different mutants and additional identified flanking open reading frames (ORFs) is shown in Figure 1.

\section{luxAB gene expression in the rhizosphere.}

In order to test if the naphthalene degradation genes in PCL1444 are expressed in the rhizosphere, Tn5luxAB derivatives of PCL1444 were inoculated on sterile Barmultra grass seedlings. Bioluminescence was detected on X-ray films after 6 or 7 days of plant growth. As shown in Figure 2 for derivatives PCL1456 (Fig. 2A), PCL1470 (Fig. 2B), and PCL1455 (Fig. 2C), expression of the $\operatorname{lu} x A B$ reporter genes was observed as dark spots along the grass roots. Bacterial numbers of strain PCL1444 decreased from approximately $10^{6}$ to $10^{7} \mathrm{CFU}$ per $\mathrm{cm}$ at the root base to $10^{5}$ to $10^{6} \mathrm{CFU}$ per $\mathrm{cm}$ on the middle root parts to approximately $10^{4}$ to $10^{5} \mathrm{CFU}$ per $\mathrm{cm}$ on the root tip, and no differences in colonizing ability were observed between the reporter strains and the wild type (I. Kuiper, unpublished data). Regions with more bioluminescence could be observed at different positions on the roots. Controls of sterile plants and sand inoculated for 6 to 7 days with the reporter strains did not give bioluminescence on films.

\section{Influence of carbon sources on growth rate and expression of naphthalene degradation genes of PCL1444.}

$P$. putida PCL1444 mutant derivatives PCL1470 (doxA/nahAa::Tn5luxAB) and PCL1455 (nahI::Tn5luxAB) were used as bioluminescent reporter strains (luxAB insertions closest to expected promoter sequences) to further analyze in detail growth and expression of the upper and lower naphthalene catabolic operon, respectively, on the individual exudate sugars arabinose, glucose, fructose, maltose, and xylose and the organic acids succinic acid, malic acid, citric acid, pyroglutamic acid, aconitic acid, propionic acid, and fumaric acid by using these compounds as the sole carbon source in modified BM medium. Growth rates of both reporter strains and the wild-type PCL1444 appeared to be

Table 1. Organic acid and sugar composition of grass seed, seedling, and root exudate

\begin{tabular}{|c|c|c|c|}
\hline \multirow[b]{2}{*}{ Composition } & \multicolumn{3}{|c|}{ Exudate $(\mathrm{ng}) /$ seed $\pm \mathrm{SD}^{\mathrm{a}}(\%)^{\mathrm{b}}$} \\
\hline & Seed $^{c}$ & Seedling ${ }^{\mathrm{d}}$ & $\operatorname{Root}^{\mathrm{e}}$ \\
\hline \multicolumn{4}{|l|}{ Organic acid } \\
\hline Aconitic & $1 \pm 0.2(0.1)$ & $3 \pm 0.4(0.1)$ & ND \\
\hline Citric & $305 \pm 46(17)$ & $449 \pm 22(16.5)$ & $944 \pm 328(16.7)$ \\
\hline Fumaric & $5 \pm 0.9(0.3)$ & $7 \pm 0.4(0.2)$ & $19 \pm 6(0.4)$ \\
\hline Malic & $413 \pm 27(22)$ & $509 \pm 28(18.7)$ & $473 \pm 128(8.4)$ \\
\hline Oxalic & $60 \pm 18(3.4)$ & $18 \pm 6(0.7)$ & ND \\
\hline Propionic & $7 \pm 0.5(0.4)$ & $9 \pm 0.9(0.3)$ & $6 \pm 2.8(0.1)$ \\
\hline Pyroglutamic & ND & ND & $37 \pm 13(0.7)$ \\
\hline Pyruvic & ND & $38 \pm 7(1.4)$ & ND \\
\hline Succinic & $1,007 \pm 225(56)$ & $1685 \pm 109(62.0)$ & $4,177 \pm 1342(73.8)$ \\
\hline Total amount & 1,798 & 2,718 & 5,657 \\
\hline \multicolumn{4}{|l|}{ Sugar } \\
\hline Arabinose & $1,760 \pm 846(58.4)$ & $506 \pm 345(19.9)$ & ND \\
\hline Fructose & $319 \pm 143(10.6)$ & $887 \pm 16(34.9)$ & $1,724 \pm 343(38.7)$ \\
\hline Glucose & $766 \pm 164(25.4)$ & $1,065 \pm 43(41.9)$ & $2,586 \pm 519(58.2)$ \\
\hline Maltose & $32 \pm 16(1.1)$ & ND & ND \\
\hline Melibiose & $6 \pm 5(0.2)$ & ND & ND \\
\hline Ribose & $12 \pm 7(0.4)$ & $12 \pm 1(0.5)$ & $20 \pm 6(0.4)$ \\
\hline Xylose & $116 \pm 85(3.9)$ & $71 \pm 16(2.8)$ & $121 \pm 34(2.8)$ \\
\hline Total amount & 3,011 & 2,541 & 4,451 \\
\hline
\end{tabular}

${ }^{\mathrm{a}}$ Results are the mean of three high performance liquid chromatography analyses. ND = not detected, $\mathrm{SD}=$ standard deviation.

${ }^{\mathrm{b}}$ Percentage of total organic acid or sugar.

${ }^{\mathrm{c}}$ Seed exudate was collected after 2 days at $4^{\circ} \mathrm{C}$.

${ }^{\mathrm{d}}$ Seedling exudate was collected after 4 days at $28^{\circ} \mathrm{C}$.

${ }^{\text {e }}$ Root exudate was collected after 14 days at $20^{\circ} \mathrm{C}$. 
very low on arabinose, maltose, ribose, xylose, and oxalic acid (generation times of more than $400 \mathrm{~min}$ ). The generation times on propionic acid and malic acid were approximately $300 \mathrm{~min}$, and generation times on pyroglutamic acid, fumaric acid, aconitric acid, and fructose were approximately 200 min. Citric acid (approximately $130 \mathrm{~min}$ ), succinic acid (approximately $100 \mathrm{~min}$ ), and glucose (approximately $100 \mathrm{~min}$ ) showed the shortest generation times.

For both reporter strains, highest $\operatorname{lu} x A B$ expression levels were measured at the start of the logarithmic phase during growth on all tested carbon sources. Subsequently, expression was decreasing in the midlogarithmic phase and dropped to a basal constitutive level when cells entered the stationary phase. Highest expression levels in both reporter strains were observed when they were grown on glucose, succinic acid, and citric acid (Fig. 3).

Addition of naphthalene to the growth medium did not increase bioluminescence in PCL1455 and PCL1470 but, in PCL1455, the maximum level of bioluminescence was reached at an earlier stage during growth when compared with growth on glucose only (Fig. 4). The same effect was observed when naphthalene was added to BM medium without an additional carbon source, although expression levels were much lower (comparable to those on aconitic acid and ribose, Fig. 3), due to no growth.

Salicylic acid is described as an intermediate of the naphthalene degradation pathway in many Pseudomonas strains; therefore, we tested whether this substrate could induce the genes responsible for naphthalene degradation in PCL1444. When salicylic acid was added, $\operatorname{lux} A B$ expression in PCL1470 increased immediately after the addition at the start of the log-phase, reaching an approximately sixfold higher maximum expression level when compared with cells without salicylic acid. In PCL1455, salicylic acid increased lux $A B$ expression approximately fourfold. When salicylic acid was present, highest expression was observed at the start of the log phase and decreased when cells entered midlog phase (Fig. 4).

All of the described mutants (Fig. 1) showed expression of the $\operatorname{lu} x A B$ genes during growth on succinic acid. The presence of naphthalene did not change the level of expression in the upper pathway mutants. However, the addition of naphthalene slightly shifted the maximum level of bioluminescence in the lower pathway mutants (data not shown). Salicylic acid increased the expression level of all mutants. Addition of naphthalene to BM medium without an additional carbon source resulted in expression levels in the same range as those on aconitric acid and ribose (Fig. 3) in the upper pathway mutants, because no growth was possible. The lower pathway mutants showed a slightly increased bioluminescence level (Fig. 4A, as is shown in PCL1455).

\section{DISCUSSION}

P. putida PCL1444 was isolated from PAH-polluted soil and was selected based on its combined naphthalene degrading and root-colonizing abilities. Naphthalene degradation by strain PCL1444 was previously described to be very efficient after inoculation of the bacteria on Barmultra seeds or seedlings (Kuiper et al. 2001). The rhizosphere is a nutrient-rich environment when compared with bulk soil; therefore, it can function as a nutrient source for rhizosphere bacteria during rhizoremediation, making them metabolically more active. Carbon sources such as succinic acid have been described to improve the action of PAH-degrading microbes during bioremediation (Schwab et al. 1995). The success of the plant-bacterium pair in the previous study could be due to the influence of the exudate compounds of grass species Lolium multiflorum cv. Barmultra on the naphthalene-degrading ability of PCL1444. For that reason, we analyzed the composition of the Barmultra root exudate. The most abundant organic acid present in all exudates appeared to be succinic acid and the most abundant sugar in seedling and root exudates appeared to be glucose (Table 1). During plant growth, these two components probably will have the most important influence on the rhizomicrobial population. The ratio between organic acids and sugars changes during plant growth. In seed exudate, the total amount of sugars was approximately twice as high as that of organic acids. However, in seedling and root exudate, the ratio between sugars and organic acids is approximately 1 . This is different from what is observed in tomato root exudate, in which organic acids are approximately five times more abundant than sugars (Lugtenberg et al. 1999; A. H. M. Wijfjes, unpublished data). The composition of grass seed, seedling, and root exudate was not analyzed for the presence of other carbon sources such as amino acids. However, the presence of amino acids in the rhizosphere of the monocotyledonous wheat plant was shown not to be sufficient as a nutrient source for root-colonizing Pseudomonas strains (de Weger et al. 1997), because an amino acid auxotrophic mutant of strain $P$. fluorescens 5RL was not able to compete with its wild type during competitive root colonization of wheat. This is similar to what was found for auxotrophic mutants of $P$. fluorescens WCS365 colonizing the dicotyledonous tomato plant (Simons et al. 1997).

To test the influence of the individual exudate components on the naphthalene degradation genes of PCL1444, reporter strains were constructed using Tn5luxAB mutagenesis (Fig. 1, Table 2). Sequence analysis of the Tn5luxAB flanking DNA re-

Table 2. Description of transposon mutant derivatives of Pseudomonas putida strain PCL1444

\begin{tabular}{|c|c|c|c|c|}
\hline Mutant strain & Growth $^{\mathbf{a}}$ & Color $^{\mathrm{b}}$ & Sequence identity (reference) ${ }^{\mathrm{c}}$ & Predicted encoded protein \\
\hline PCL1454 & - & Normal & $\begin{array}{l}\text { Intergenic region between } \operatorname{dox} G \text { and } \operatorname{dox} H \text { (Denome et al. } \\
1993 \text { ) }\end{array}$ & None \\
\hline PCL1455 & \pm & Dark yellow & 93\% nahI (Bosch et al. 2000) & $\begin{array}{l}\text { Hydroxymuconic semialdehyde } \\
\text { dehydrogenase }\end{array}$ \\
\hline PCL1456 & - & Dark brown & 98\% doxG /nahC (Denome et al. 1993 / Boronin et al. 1989) & 1,2-Dihydroxynaphthalene dioxygenase \\
\hline PCL1470 & - & Normal & $98 \%$ doxA/nahAa (Simon et al. 1993) & $\begin{array}{l}\text { Naphthalene } 1,2 \text {-dioxygenase system, } \\
\text { ferredoxin-nad }{ }^{+} \text {reductase }\end{array}$ \\
\hline PCL1471 & - & Normal & 99\% doxJ (Denome et al. 1993) & $\begin{array}{l}\text { 2-Hydroxychromene-2-carboxylate } \\
\text { isomerase }\end{array}$ \\
\hline PCL1472 & - & Normal & 97\% doxF/nahF (Boronin et al. 1989; Denome et al. 1993) & Salicylaldehyde dehydrogenase \\
\hline PCL1475 & \pm & Normal & 97\% nahM (Bosch et al. 2000) & 4-Hydroxy-2-oxovalerate aldolase \\
\hline
\end{tabular}

${ }^{a}$ Growth on BM-naphthalene medium is indicated as no growth (-) and delayed growth ( \pm ).

${ }^{\mathrm{b}}$ Color on BM-naphthalene is indicated as normal when no difference with the wild-type PCL1444 is observed; this table indicates when the medium colors differently.

${ }^{c}$ Sequence identity of inserted open reading frame on amino acid level. 
gions showed high homology with both the dox and nah upper pathways of Pseudomonas strain C18 (Denome et al. 1993) and of various $P$. putida strains (Boronin et al. 1989; Simon et al. 1993), respectively, and with the lower pathway of $P$. stutzeri (Bosch et al. 2000). The naphthalene catabolic genes in Pseudomonas spp. have been described to be organized in two operons, referred to as the upper and lower catabolic pathway (Fig. 1). The upper pathway is involved in the degradation of naphthalene to salicylic acid. Subsequently, salicylic acid is the substrate for the lower pathway, which converts salicylic acid to acetylaldehyde and pyruvate (Yen and Serdar 1988). The sequenced fragments of the genes of the $\operatorname{dox} F, \operatorname{dox} G, \operatorname{dox} H$, and doxI homologues in PCL1444 (Fig. 1) indicate a gene order in PCL1444 similar to that described for the upper pathways of other Pseudomonas strains mentioned above. The sequences of the DNA fragments of the nahM and nahI homologues from mutants PCL1455 and PCL1475 show that, in strain PCL1444, the nahI and nahN homologues and also the nahO and nahM homologues are located next to each other, as was also described for P. stutzeri (Bosch et al. 2000) (Fig. 1). According to Denome and associates (1993), mutations in $\operatorname{dox} G$ result in the accumulation of 1,2-dihydroxynaphthalene (Fig. 1), which can convert into a dark-brown-colored quinone at neutral $\mathrm{pH}$. This explains the dark color of cultures of PCL1456. Pigmentation due to the presence of intermediates is lacking in PCL1472, which is explained by the insertion of the first gene of the upper pathway for naphthalene degradation. The inserted ORFs in PCL1455 and PCL1475 showed highest homology with genes from the lower pathway for naphthalene degradation of P. stutzeri. The very slow growth on plates with naphthalene as the sole carbon source, which was observed after incubation for more than 3 days, can be explained by the presence of the intact upper degradation pathway. Probably, these mutants are able to derive sufficient energy for growth from conversion of naphthalene to salicylic acid.

Studies on growth rates of PCL1444 and its mutant derivatives showed that growth on the most dominant carbon sources of Barmultra root exudate, succinic acid and glucose (Table 1), resulted in the highest growth rates when compared with the other carbon sources present in the grass root exudate. Apparently, the selection for an efficient grass root-colonizing bacterium resulted in the isolation of a strain that can metabolize the major exudate components very efficiently.

To test whether the naphthalene catabolic genes are expressed in the grass rhizosphere with a second experimental approach, the mutant strains were used to analyze $\operatorname{lux} A B$ ex-

\section{A Upper pathway}

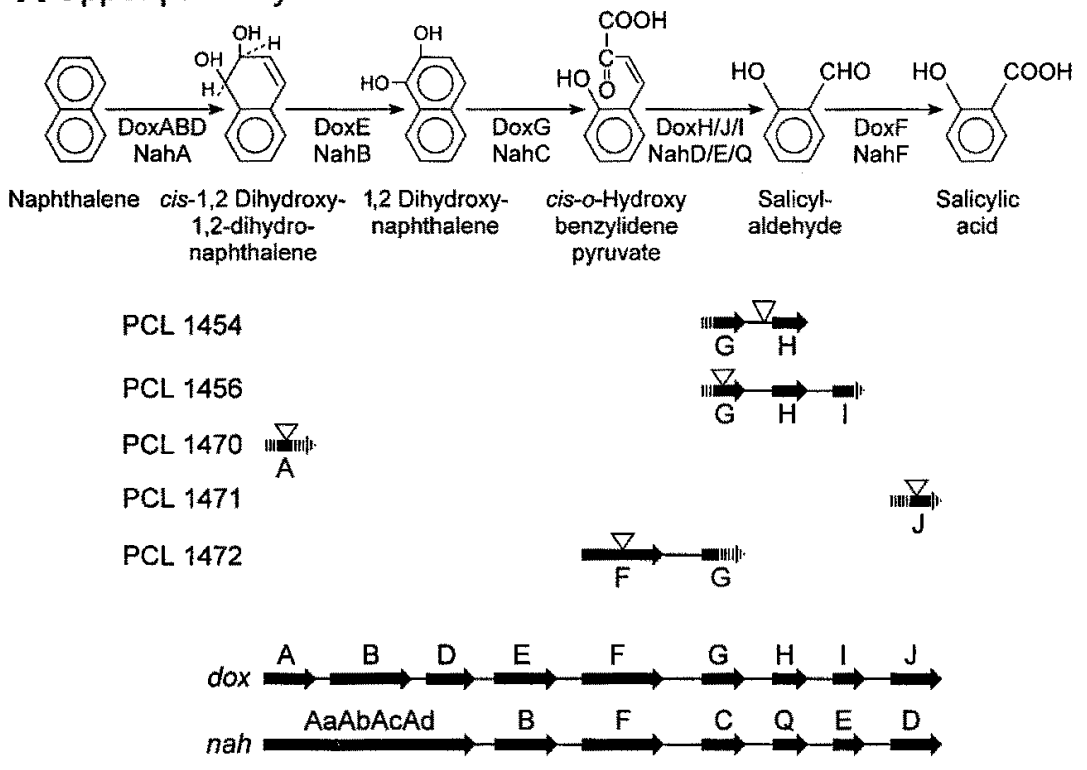

B Lower pathway

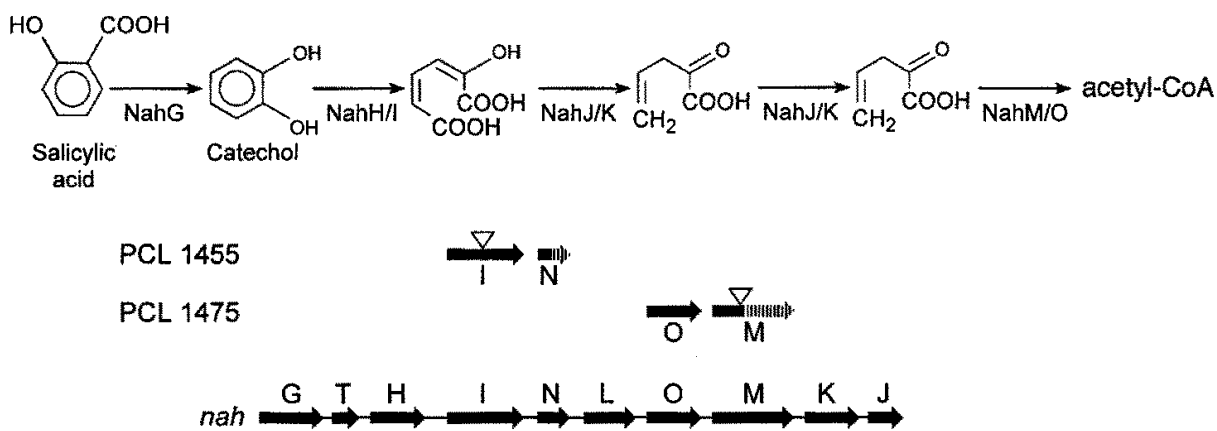

Fig. 1. Schematic map of sequenced Tn5luxAB derivatives of PCL1444. A, Mutants PCL1456, PCL1470, PCL1471, and PCL1472 all have inserts in genes encoding enzymes of the upper pathway of naphthalene degradation. B. Mutants PCL1455 and PCL1475 have inserts in genes encoding enzymes of the lower pathway of naphthalene degradation. The Tn5luxAB insertion is indicated with a triangle and arrows indicate the direction of transcription. Dashed arrows indicate the part of the open reading frame that has not been sequenced in the mutant strain, but from which its presence is based in literature. 
pression along the root system. The presence of bacteria with expression of the naphthalene catabolic genes along the entire root system can explain the naphthalene degradation in soil in the rhizosphere of Barmultra grass (Fig. 2). The observation of spots with more bioluminescence on local sites of the roots can be due to a local high concentration of exuded nutrients, resulting in either high transcription of the respective naphthalene catabolic operon or high cell density, or both. The presence of these local spots with high bioluminescence indicate that concentrations of exudate nutrients can vary enormously at different sites on the root, making nutrient concentrations in the rhizosphere difficult to predict.

To test the influence of the individual carbon sources present in the exudate on the expression of the naphthalene catabolic genes in PCL1444, derivative strains PCL1470 (doxA/nahAa::Tn5luxAB) and PCL1455 (nahI::Tn5luxAB) were used as reporter strains for the upper and lower pathway, respectively. The $\operatorname{lu} x A B$ genes are expressed at high levels in the presence of glucose, fructose, succinic acid, and citric acid (Fig. 3). This observation shows that the presence of the major grass exudate components (Table 1) results in high expression of the naphthalene catabolic genes in PCL1444. In the presence of naphthalene, the lower pathway reporter PCL1455 reached the maximum bioluminescence level earlier during growth (Fig. 4A), but naphthalene did not induce the upper pathway reporter strain PCL1470 (Fig. 4B). Yen and Serdar (1988) and Neilson and associates (1999) also observed that naphthalene does not induce the naphthalene catabolic operons. They reported that the regulation of the naphthalene upper and lower catabolic operons in various Pseudomonas strains depends on the product of a regulatory gene, nahR, and on the presence of salicylic acid (or a derivative) as an inducer. Our results (Fig. 4) show that, also in PCL1444, naphthalene degradation is strongly induced by salicylic acid. Both pathways are induced immediately after addition of salicylic acid, whereas

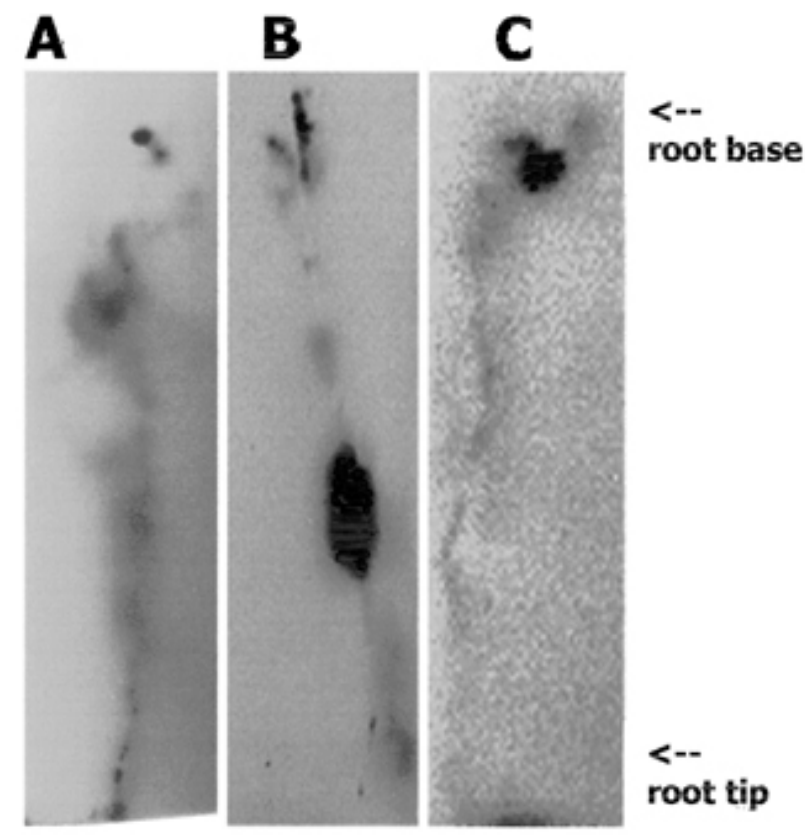

Fig. 2. Expression of naphthalene degradation genes on a root of Lolium multiflorum cv. Barmultra grass. Sterile seedlings were inoculated with $\mathbf{A}$, PCL1456 (doxG/nahC::Tn5luxAB), B, PCL1470 (doxA/nahAa::Tn5luxAB), and C, PCL1455 (nahI::Tn5luxAB) and planted in the gnotobiotic sand system. After 7 days of growth, plants were removed from the growth tubes and roots were placed separate from each other on moistened filter paper with the substrates naphthalene and n-decyl-aldehyde, sealed in plastic, and incubated with an X-ray film. no effect of salicylic acid was observed on growth rate (data not shown). In reporter strain PCL1455, the upper pathway is unaffected by the Tn5 insertion. In the presence of naphthalene, the intermediate salicylic acid can be formed. This could explain the shifted maximum bioluminescence level (Fig. 4A), although the level of expression is not significantly higher when compared with growth on glucose only. However, wildtype PCL1444 is not able to grow on salicylic acid as the sole carbon source (data not shown), which could indicate that salicylic acid is not an intermediate in the degradation of naphthalene in PCL1444. An alternative explanation is that the presence of a part of the lower pathway results in the conversion of salicylic acid to other intermediates that cannot function as inducers. The presence of salicylic acid in the rhizosphere as a result of its production by the plant or other microbes (De Meyer et al. 1999) could make naphthalene degradation in the rhizosphere more efficient. This opens opportunities for improvement of rhizoremediation by using plants that are modified to overproduce salicylic acid (Verberne et al. 2000) and that, subsequently, can exude this into the rhizosphere.

Strain PCL1444 has been selected for efficient grass root colonization. Furthermore, it degrades naphthalene in the grass rhizosphere and even protects the plants against naphthalene phytotoxicity (Kuiper et al. 2001). Our present results indicate that strain PCL1444 was, in fact, selected for fast growth on the major root exudate components. Whether the high expression of the naphthalene catabolic genes in the presence of these major exudate components is also the result of this selection or whether it is lucky coincidence is not known.

\section{MATERIALS AND METHODS}

\section{Bacterial strains and growth conditions.}

Bacterial strains used are listed in Table 3. Pseudomonas strains were cultured at $28^{\circ} \mathrm{C}$ in liquid King's medium B (KB) (King et al. 1954) under vigorous shaking. Escherichia coli strains were grown in liquid Luria Bertani medium (LB) (Sambrook et al. 1989) at $37^{\circ} \mathrm{C}$ under vigorous shaking. Media were solidified with $1.8 \%$ agar (Bacto Agar, Difco Laboratories, Detroit) and, when appropriate, kanamycin and carbenicillin were added to final concentrations of 50 and $100 \mu \mathrm{g}$ per $\mathrm{ml}$, respectively. For growth on naphthalene (Sigma-Aldrich, St. Louis) as the sole carbon source, succinic acid from standard BM medium (Lugtenberg et al. 1999) was replaced by naphthalene as the sole carbon source (BM-naphthalene). In liquid culture, naphthalene was added as crystals; in plates, naphthalene crystals were put in the lid of the petri dish.

\section{Generation and isolation of naphthalene degradation defective mutants.}

Transposon mutants of Pseudomonas were generated by a triparental mating with $E$. coli strains containing plasmid pRL1063a, which harbors a promoterless Tn5luxAB transposon (Wolk et al. 1991), and helper plasmid pRK2013 (Ditta et al. 1980). Mutants defective in naphthalene degradation were isolated after screening for the inability to grow on solidified BMnaphthalene medium. To recover the regions flanking the site in which the Tn5luxAB had inserted, chromosomal DNA of the mutants was digested using EcoR1 or ClaI. Recirculation of the $\operatorname{Tn} 5 \operatorname{lux} A B$ with the flanking chromosomal DNA was performed by ligation of the digested chromosomal DNA. Nucleotide sequencing of the flanking regions starting from the Tn5luxAB borders was performed by BaseClear (Leiden, The Netherlands) with primers oMP407 and oMP408, which are homologous to the left border (5' TACTAGATTCAATGCTATCAATGAG $3^{\prime}$ ) and the right border (5' AGGAGGTCACATGGAATATCAGAT 3'), respectively. Additional sequenc- 
ing was performed with internal primers designed on the basis of sequenced DNA of plasmid pMP5407. All general DNA techniques were performed as described by Sambrook and associates (1989). DNA sequences were analyzed using DNAman software (Lynnon Biosoft, Quebec, Canada) and compared with the DNA data bank using the NCBI Blast search program (Altschul et al. 1997).

\section{Analysis of seed, seedling, and root exudate.}

Seed (200) of grass species Lolium multiflorum cv. Barmultra (provided by Barenbrug Research, Wolfheze, The Netherlands) were washed in sterile water for $2 \mathrm{~h}$ and surface sterilized in 100 $\mathrm{ml}$ of $0.1 \%$ sublimate $\left(\mathrm{HgCl}_{2}\right)$ solution for $2 \mathrm{~min}$. Subsequently, seed were washed in 11 of sterile water and placed on moistened filter paper in petri dishes (20 seeds in each). Dishes were placed in the dark at $4^{\circ} \mathrm{C}$ for $48 \mathrm{~h}$. Subsequently, seed were allowed to

\section{A PCL1455 (nahI::Tn5/uxAB)}

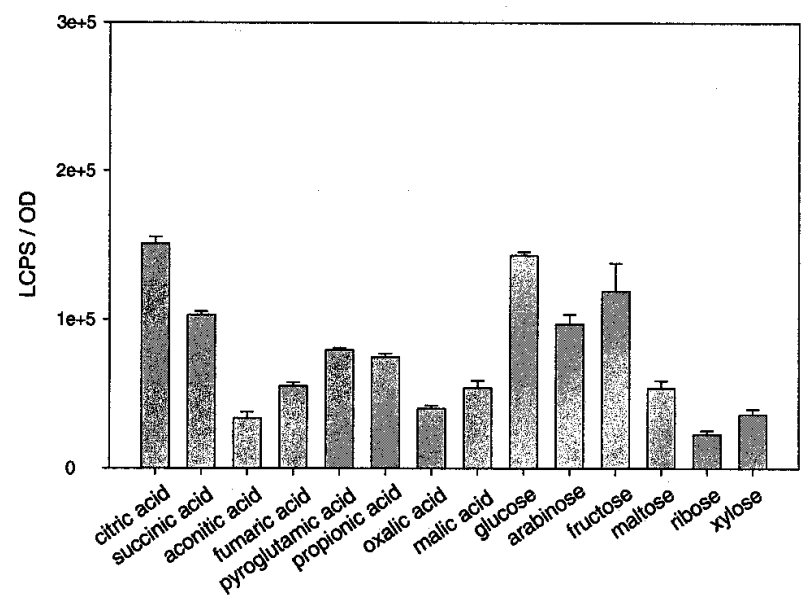

\section{B PCL1470 (doxA / nahAa::Tn5/uxAB)}

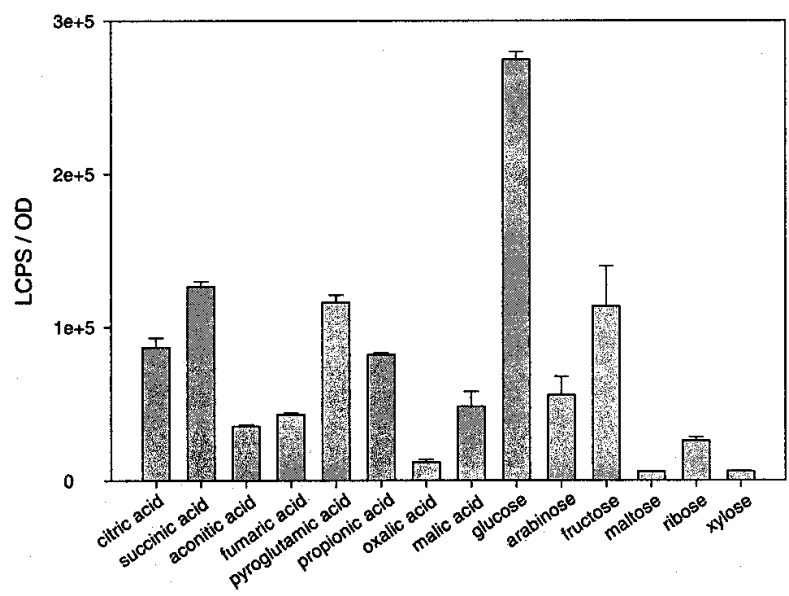

Fig. 3. Expression of naphthalene degradation genes during growth on individual root exudate components. Luminescence counts per second per optical density (OD) unit were measured during growth of $\mathbf{A}$, PCL1455 (nahI::Tn5luxAB) and B, PCL1470 (doxA/nahAa::Tn5luxAB) in minimal medium with root exudate components as the sole carbon sources. Cultures grown overnight in the medium to be tested were washed and diluted to a final $\mathrm{OD}_{620}$ of 0.1 in fresh medium. After various time intervals during growth, triplicate samples were taken and bioluminescence was measured after addition of the substrate. Maximum expression values detected in the log phase are depicted. germinate at $28^{\circ} \mathrm{C}$ for 4 days. In order to determine seed and seedling exudate composition, filter papers were extracted after $48 \mathrm{~h}$ of swelling at $4^{\circ} \mathrm{C}$ and after 4 days of germination at $28^{\circ} \mathrm{C}$, respectively. Extractions were performed using $100 \mathrm{ml}$ of sterile water for each filter, and the combined extracts of 10 filters were evaporated to dryness at $45^{\circ} \mathrm{C}$ under vacuum. Extracts were dissolved in $5 \mathrm{ml}$ of sterile water and sterilized by membrane filtration. In order to obtain root exudate, germinated seedlings were cultivated under sterile conditions in glass cylinders and placed in 250-ml flasks containing $50 \mathrm{ml}$ of a sterile nutrient solution consisting of $\mathrm{Ca}\left(\mathrm{NO}_{3}\right)_{2}, \mathrm{MgSO}_{4}, \mathrm{KNO}_{3}$, and $\mathrm{KH}_{2} \mathrm{PO}_{4}$ in concentrations of $165,20,30$, and $30 \mathrm{mg}$ per liter of deionized water, respectively. After sterilization, $\mathrm{pH}$ was adjusted to 7.2 to 7.4 . In all, five plants were cultivated in one flask. Plants were grown at $21^{\circ} \mathrm{C}$ with a $16-\mathrm{h}$ light period at 10,000 lux. For sample preparation, 60 plants were used.

The seed and root exudate fractions were concentrated on the strong cation exchanger DOWEX $50 \times 8(0.07$ to $0.13 \mu \mathrm{m})$

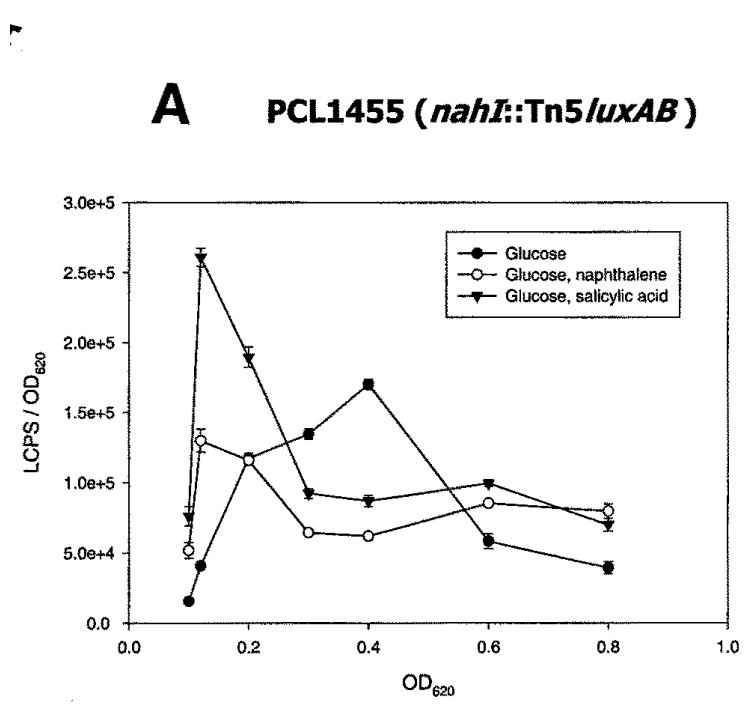

B PCL1470 (doxA / nahAa:Tn5/uXAB)

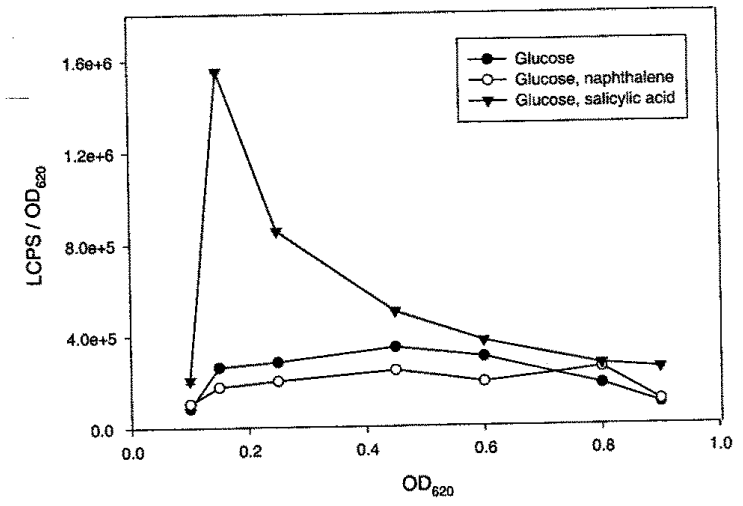

Fig. 4. Expression of the naphthalene degradation genes of Pseudomonas putida PCL1444 in the presence of naphthalene and salicylic acid. Luminescence counts per second per optical density (OD) unit of $\mathbf{A}$, PCL1455 and B, PCL1470 were determined. Cells were grown overnight in BM-glucose, washed, and inoculated to a final $\mathrm{OD}_{620}$ of 0.1 in fresh BM medium containing glucose, glucose and salicylic acid, and glucose and naphthalene. Triplicate samples were taken at various ODs and bioluminescence was measured directly after addition of n-decylaldehyde. 
(Supelco Gland, Buchs, Switzerland) in the $\mathrm{H}^{+}$cycle. For this purpose, diluted seed and root exudates were passed through the $1.5-$ by $-1.0-\mathrm{cm}$ column at a rate of $1 \mathrm{ml}$ per min. Subsequently, the column was washed with $10 \mathrm{ml}$ of deionized water and the $15-\mathrm{ml}$ end volume was evaporated to dryness at $45^{\circ} \mathrm{C}$ under vacuum. The residue was dissolved in $500 \mu \mathrm{l}$ of deionized water.

Quantitative analysis of organic acids was carried out using a JASCO LC-900 series high performance liquid chromatography (HPLC) system (Jasco International Co., Ltd., Victoria, British Columbia, Canada) that was equipped with a Rheodyne (Rheodyne, Torrance, CA. U.S.A.) Model 7125 100- $\mu \mathrm{m}$ valve loop injector, a PU-980 pump, a degassing module DG-980-50, a ternary gradient unit LG-980-02, a UV detector UV-975, and a computer with BORWIN (JMBS Developments, Fontaine, France) chromatography software connected to the HPLC system via JASCO LC-Net.

Organic acids were separated using an ion-exchange SUPELCOGEL C-610H, 213-4M23 (Supelco Gland) column (30 $\mathrm{cm}$ by $7.8 \mathrm{~mm}$ ). The mobile phase was $10.0 \mathrm{mM} \mathrm{H}_{3} \mathrm{PO}_{4}$ at a flow rate of $0.7 \mathrm{ml} / \mathrm{min}$. Separation was carried out at $30^{\circ} \mathrm{C}$. The wavelength of the UV detector was $210 \mathrm{~nm}$.

Sugars were separated using a stainless steel column (25.0 by $4.6 \mathrm{~mm}$ ) filled with SUPERCOSIL LC-NH2 (Supelco Gland) with a particle size of $5 \mu \mathrm{m}$. Separation was carried out at $30^{\circ} \mathrm{C}$. The mobile phase was a gradient of acetonitril and water. For detection of reducing carbohydrates, the postcolumn labeling method was used. This method involves a color reaction of sugars with tetrazolium blue in alkaline media (Mopper and Degens 1972). A 3-m reaction coil of Teflon tubing was placed between the column exit and the photometer at the cuvette exit. The eluant and dye were pumped with LKB 2150 HPLC piston pumps. The dye consisted of $2.0 \mathrm{~g}$ o 2,3,5-triphenyl-tetrazoliumchloride (Fluka Chemie, Zwijndrecht, The Netherlands) dissolved in 1.0 liter of $0.18 \mathrm{M} \mathrm{NaOH}$. The eluant flow rate was $0.8 \mathrm{ml}$ per min and that of the tetrazolium reagent was $0.2 \mathrm{ml}$ per min. The temperature of the water bath (Julabo MWB, Seelbach, Germany) with reaction coil was $85^{\circ} \mathrm{C}$ and the reaction time was approximately $80 \mathrm{~s}$. Adsorption at a wave length of $487 \mathrm{~nm}$ was detected using an adsorption detector (Jasco UV detector UV-975). Some sugars can have similar retention times; therefore, the purity of the peaks in some cases was analyzed on a second chromatographic column (DEAE-Si100).

Sugars and organic acids were identified and quantified by injecting aliquots of 10 and $100 \mu \mathrm{l}$, respectively, of the exudate. Each peak was identified by retention times of known carbohydrates and organic acids standard solutions and also on addition of each known carbohydrate and organic acids standard individually to the unknown sample. Retention times and peak areas were recorded to calculate chromatographic parameters. The total analysis time was $35 \mathrm{~min}$ for carbohydrates and 20 min for organic acids.

\section{In vitro $\operatorname{lux} A B$ expression analysis.}

In order to measure luxAB expression of Tn5lux $A B$ reporter strains, cells were grown overnight in the appropriate medium and subsequently diluted to an optical density $\left(\mathrm{OD}_{620}\right)$ of 0.1 in $10 \mathrm{ml}$ of fresh medium. $\mathrm{OD}_{620}$ was measured at various time intervals and triplicate samples of $100 \mu \mathrm{l}$ were taken to quantify LuxAB activity. For this purpose, $100 \mu \mathrm{l}$ of the substrate for the bioluminescence reaction, a $0.2 \% \mathrm{n}$-decyl-aldehyde (Sigma-Aldrich, Zwijndrecht, The Netherlands) in $2.0 \%$ bovine serum albumin (BSA) (Sigma-Aldrich) solution, was mixed with the sample. Bioluminescence was quantified directly after sampling using a luminescence counter (MicroBeta 1450 Trilux, Wallac, Turku, Finland). The influence of individual root exudate components arabinose, glucose, sucrose, maltose, ribose, xylose, fumaric acid, oxalic acid, aconitric acid, propionic acid, pyroglutamic acid, succinic acid, citric acid, and malic acid (Sigma-Aldrich) on $\operatorname{lux} A B$ expression was tested by using these components as the sole carbon source in modified BM medium in a final concentration of $2.0 \mathrm{mM}$. Naphthalene or salicylic acid (Sigma-Aldrich) was added as crystals or in a final concentration of $1.0 \mathrm{mM}$, respectively.

\section{Gene expression analysis in the rhizosphere.}

Sterile seedlings of grass species Lolium multiflorum cv. Barmultra were inoculated and planted in the gnotobiotic system as

Table 3. Bacterial strains and plasmids used

\begin{tabular}{|c|c|c|}
\hline $\begin{array}{l}\text { Strains and } \\
\text { plasmids }\end{array}$ & Relevant characteristics & Reference or source \\
\hline \multicolumn{3}{|l|}{ Pseudomonas } \\
\hline PCL1444 & Wild-type $P$. putida strain, efficient grass root colonizer and naphthalene degrader & Kuiper et al. 2001 \\
\hline PCL1454 & $\begin{array}{l}\text { Derivative of PCL1444 with Tn5luxAB in a DNA region between } \operatorname{dox} G / n a h C \text { homologue and } \\
\text { doxF/nahF homologue }\end{array}$ & Kuiper et al. 2001 \\
\hline PCL1455 & Derivative of PCL1444 with Tn5luxAB in nahI homologue & This study \\
\hline PCL1456 & Derivative of PCL1444 with Tn5luxAB in $\operatorname{dox} G / n a h C$ homologue & This study \\
\hline PCL1470 & Derivative of PCL1444 with Tn5luxAB in doxA/nahAa homologue & This study \\
\hline PCL1471 & Derivative of PCL1444 with Tn5luxAB in doxJ/nahD homologue & This study \\
\hline PCL1472 & Derivative of PCL1444 with Tn5luxAB in doxF/nahF homologue & This study \\
\hline PCL1475 & Derivative of PCL1444 with Tn5luxAB in nahM homologue & This study \\
\hline \multicolumn{3}{|c|}{ Escherichia coli } \\
\hline DH5 $\alpha$ & $\begin{array}{l}\text { endAl gyrSA96 hrdR17(rK- } \mathrm{mK} \text {-) supE44 recAl; general purpose host strain used for } \\
\text { transformation and propagation of plasmids }\end{array}$ & Boyer and Roulland-Dussoix 1969 \\
\hline \multicolumn{3}{|l|}{ Plasmids } \\
\hline pRL1063a & Plasmid containing a Tn5 with promoterless $\operatorname{lu} x A B, \mathrm{Km}^{\mathrm{r}}$. & Wolk et al. 1991 \\
\hline pMP5406 & $\begin{array}{l}\text { pRL1063a derivative recovered from chromosomal DNA of PCL1454 after digestion with } \\
\text { EcoRI }\end{array}$ & Kuiper et al. 2001 \\
\hline pMP5407 & $\begin{array}{l}\text { pRL1063a derivative recovered from chromosomal DNA of PCL1456 after digestion with } \\
\text { EcoRI }\end{array}$ & This study \\
\hline pMP5429 & pRL1063a derivative recovered from chromosomal DNA of PCL1455 after digestion with ClaI & This study \\
\hline pMP5438 & $\begin{array}{l}\text { pRL1063a derivative recovered from chromosomal DNA of PCL1470 after digestion with } \\
\text { EcoRI }\end{array}$ & This study \\
\hline pMP5440 & $\begin{array}{l}\text { pRL1063a derivative recovered from chromosomal DNA of PCL1475 after digestion with } \\
\text { EcoRI }\end{array}$ & This study \\
\hline pMP5446 & pRL1063a derivative recovered from chromosomal DNA of PCL1471 after digestion with ClaI & This study \\
\hline pMP5448 & pRL1063a derivative recovered from chromosomal DNA of PCL1472 after digestion with ClaI & This study \\
\hline
\end{tabular}


described by Simons and associates (1996). After 7 days of growth, plants were isolated from the tubes and adhering sand was gently removed from the roots. Plants were incubated on filter paper, moistened with phosphate-buffered saline (PBS), and the substrates n-decyl-aldehyde and naphthalene (SigmaAldrich) were added on the filter paper. The filter papers with plants and substrates were sealed in plastic to prevent evaporation of moisture and, together with an X-ray film (Fuji Medical X-ray film, Fuji Photo Film Co., Ltd., Tokyo), incubated in a dark box as described by de Weger and associates (1997). As a control, sterile plants were incubated with the substrates and exposed to an X-ray film.

\section{ACKNOWLEDGMENTS}

We thank C. Meuwly for technical assistance. I. Kuiper was supported by a grant from the Earth and Life Sciences Council NWO and the Technology Foundation STW, Project GBI 55.3868(73-95); and L. Kravchenko was supported by a NWO grant for Russian collaborations.

\section{LITERATURE CITED}

Altschul, S. E., Madden, T. L., Schaffer, A. A., Zhang, J., Zhang, Z., Miller, W., and Lipman, D. J. 1997. Gapped BLAST and PSI-BLAST: A new generation of protein database search programs. Nucleic Acids Res. 25:3389-3402.

Anderson, T. A., Guthrie, E. A., and Walton, B. T. 1993. Bioremediation in the rhizosphere. Environ. Sci. Technol. 27:2630-2636.

Aprill, W., and Sims, R. C. 1990. Evaluation of the use of prairie grasses for stimulating polycyclic aromatic hydrocarbon treatment in soil. Chemosphere 20:253-265.

Bizily, S. P., Rugh, C. L., and Meagher, R. B. 2000. Phytodetoxification of hazardous organomercurials by genetically engineered plants. Nat. Biotechnol. 18:213-217.

Boronin, A. M., Tsoi, T. V., Kosheleva, I. A., Arinbasarov, M. U., and Adanin, V. M. 1989. Cloning of Pseudomonas putida genes responsible for the primary stages of oxidation of naphthalene in Escherichia coli cells. Genetika 25:226-237.

Bosch, R., Garcia-Valdez, E., and Moore, E. R. B. 2000. Complete nucleotide sequence and evolutionary significance of a chromosomally encoded naphthalene-degradation lower pathway from Pseudomonas stutzeri AN10. Gene 245:65-74.

Boyer, H. W., and Roulland-Dussoix, D. 1969. A complementation analysis of the restriction and modification of DNA in Escherichia coli. J. Mol. Biol. 41:459-472.

De Meyer, G., Capieau, K., Audenaert, K., Buchala, A., Métraux, J.-P., and Höfte, M. 1999. Nanogram amounts of salicylic acid produced by the rhizobacterium Pseudomonas aeruginosa 7NSK2 activate the systemic acquired resistance pathway in bean. Mol. Plant-Microbe Interact. 12:450-458.

Denome, S. A., Stanley, D. C., Olson, E. S., and Young, K. D. 1993. Metabolism of dibenzothiophene and naphthalene in Pseudomonas strains: Complete DNA sequence of an upper naphthalene catabolic pathway. J. Bacteriol. 175:6890-6901

de Weger, L. A., Kuiper, I., van der Bij, A. J., and Lugtenberg, B. J. J. 1997. Use of a lux-based procedure to rapidly visualize root colonization by Pseudomonas fluorescens in the wheat rhizosphere. Antonie Leeuwenhoek 72:365-372.

Ditta, G., Stanfield, S., Corbin, D., and Helsinki, D. R. 1980. Broad host range DNA cloning system for Gram-negative bacteria: Construction of a gene bank of Rhizobium meliloti. Proc. Natl. Acad. Sci. U.S.A. 77:7347-7351.

Erickson, L. E. 1997. An overview of research on the beneficial effects of vegetation in contaminated soil. Ann. N. Y. Acad. Sci. 829:30-35.
Gleba, D., Borisjuk, N. V., Borisjuk, L. G., Kneer, R., Poulev, A. Skarzhinskaya, M., Dushenkov, S., Logendra, S., Gleba, Y., and Raskin, I. 1999. Use of plants roots for phytoremediation and molecular farming. Proc. Natl. Acad. Sci. U.S.A. 96:5973-5977.

King, E. O., Ward, M. K., and Raney, D. E. 1954. Two simple media for the demonstration of pyocyanin and fluorescin. J. Lab. Clin. Med. 44:301-307.

Kingsley, M. T., Fredrickson, J. K., Metting, F. B., and Seidler, R. J. 1994 Environmental restoration using plant-microbe bioaugmentation. Pages 287-292 in: Bioremediation of Chlorinated and Polycyclic Aromatic Hydrocarbon Compounds. R. E. Hinchee, A. Leeson, L. Semprini, and S. K. Ong, eds. Lewis Publishers, Boca Raton, FL, U.S.A

Kuiper, I., Bloemberg, G. V., and Lugtenberg, B. J. J. Selection of a plant-bacterium pair as a novel tool for rhizostimulation of polycyclic aromatic hydrocarbon-degrading bacteria. Mol. Plant-Microbe Interact. In press.

Lugtenberg, B. J. J., Kravchenko, L. V., and Simons, M. 1999. Tomato seed and root exudate sugars: Composition, utilization by Pseudomonas biocontrol strains and role in rhizosphere colonization. Environ. Microbiol. 1:439-446.

Lynch, J. M., and Whipps, J. M. 1990. Substrate flow in the rhizosphere. Plant Soil 129:1-10.

Meagher, R. B. 2000. Phytoremediation of toxic elemental organic pollutants. Curr. Opin. Plant Biol. 3:162.

Mopper, K., and Degens, E. T. 1972. A new chromatographic sugar autoanalyzer with sensitivity of $10^{-10}$ moles. Anal. Biochem. 45:147-153.

Neilson, J. W., Pierce, S. A., and Maier, R. M. 1999. Factors influencing expression of luxCDABE and nah genes in Pseudomonas putida RB1353(NAH,pUTK9) in dynamic systems. Appl. Environ. Microbiol. 65:3473-3482.

Rovira, A. D. 1956. Plant root excretions in relation to the rhizosphere effect III. The effect of root exudate on the numbers and activity of micro-organisms in soil. Plant Soil 7:209-217.

Sambrook, J., Fritsch, E. F., and Maniatis, T. 1989. Molecular Cloning: A Laboratory Manual. 2nd ed. Cold Spring Harbor Laboratory, Cold Spring Harbor, NY, U.S.A.

Schwab, A. P., Banks, M. K., and Arunachalam, M. 1995. Biodegradation of polycyclic aromatic hydrocarbons in rhizosphere soil. Pages 23-29 in: Bioremediation of Recalcitrant Organics. R. E. Hinchee, D. B Anderson, and R. E. Hoeppel, eds. Battelle Memorial Institute, Columbus, OH, U.S.A.

Simon, M. J., Osslund, T. D., Saunders, R., Ensley, B. D., Suggs, S., Harcourt, A., Suen, W. C., Cruden, D. L., Gibson, D. T., and Zylstra, G. J. 1993. Sequences of genes encoding naphthalene dioxygenase in Pseudomonas putida strains G7 and NCIB 9816-4. Gene 127:31-37.

Simons, M., Permentier, H. P., de Weger, L. A., Wijffelman, C. A., and Lugtenberg, B. J. J. 1997. Amino acid synthesis is necessary for tomato root colonization by Pseudomonas fluorescens strain WCS365. Mol. Plant-Microbe Interact. 10:102-106.

Simons, M., van der Bij, A. J., Brand, I., de Weger, L. A., Wijffelman, C. A., and Lugtenberg, B. J. J. 1996. Gnotobiotic system for studying rhizosphere colonization by plant growth-promoting Pseudomonas bacteria. Mol. Plant-Microbe Interact. 9:600-607.

Verberne, M. C., Verpoorte, R., Bol, J. F., Mercado-Blanco, J., and Linthorst, J. M. 2000. Overproduction of salicylic acid in plants by bacterial transgenes enhances pathogen resistance. Nat. Biotechnol. 18:779-783.

Walton, B. T., and Anderson, T. A. 1990. Microbial degradation of trichloroethylene in the rhizosphere: Potential application to biological remediation of waste sites. Appl. Environ. Microbiol. 56:1012-1016.

Wolk, C. P., Cai, Y., and Panoff, J.-M. 1991. Use of a transposon with luciferase as a reporter to identify environmentally responsive genes in cyanobacterium. Proc. Natl. Acad. Sci. U.S.A. 88:5355-5359.

Yee, D. C., Maynard, J. A., and Wood, T. K. 1998. Rhizoremediation of trichloroethylene by a recombinant, root-colonizing Pseudomonas fluorescens strain expressing toluene ortho-monooxygenase constitutively. Appl. Environ. Microbiol. 64:112-118.

Yen, K. M., and Serdar, C. M. 1988. Genetics of naphthalene catabolism in pseudomonads. CRC Crit. Rev. Biotechnol. 15:247-268. 